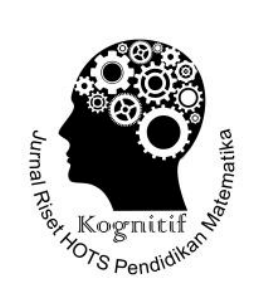

\title{
Penerapan Model Problem Based Learning Dengan Pemberian Tugas Proyek Terhadap Hasil Belajar Matematika
}

\author{
Nurafni, Nenny Indrawati
}

How to cite : Nurafnni, Indarawi, N, , 2021. Penerapan Model Problem Based Learning Dengan Pemberian Tugas Proyek Terhadap Hasil Belajar Matematika. Kognitif: Jurnal Riset HOTS Pendidikan Matematika. 1(2). 8188. https://doi.org/10.51574/kognitif.v1i2.71

To link to this article : https://doi.org/10.51574/kognitif.v1i2.71

Opened Access Article

Published Online on 1 Desember 2021

勿 Submit your paper to this journal 


\title{
Penerapan Model Problem Based Learning Dengan Pemberian Tugas Proyek Terhadap Hasil Belajar Matematika
}

\author{
Nurafni ${ }^{1}$, Nenny Indrawati ${ }^{1^{*}}$ \\ ${ }^{1}$ Program Studi Pendidikan Matematika, Universitas Sulawesi Barat
}

\begin{tabular}{l} 
Article Info \\
\hline Article history: \\
Received Jul 24, 2021 \\
Accepted Sept 12, 2021 \\
Published Online Dec 1, 2021 \\
\hline Keywords: \\
Problem Based Learning model \\
Project Assignments \\
Observation Sheets \\
Student Responses \\
Learning Outcomen Test
\end{tabular}

\section{Pendahuluan}

Pendidikan merupakan proses interaksi yang mendorong terjadinya belajar yang dikemukakan oleh dimyati \& mudjiono (Subekti, 2017:130). Proses interaksi yang mendorong terjadinya belajar merupakan suatu kegiatan yang direncanakan untuk merangsang siswa melakukan aktivitas untuk menemukan pengetahuannya. Dengan menemukan sendiri

\begin{abstract}
Penelitian ini merupakan penelitian tindakan kelas yang telah dilaksanakan dalam 2 siklus bertujuan untuk mengetahui hasil belajar matematika pada siswa Kelas XI MIPA 2 SMAN 1 Pamboang dengan menerapkan model problem based learning dengan pemberian tugas proyek. Sampel penelitian ini adalah siswa kelas XI MIPA 2 SMAN 1 Pamboang dengan jumlah 18 siswa. Teknik analisis data dilakukan secara teknik analisis data kualitatif dan teknik analisis data kuantitatif. Keberhasilan penelitian dapat dilihat dari pencapaian indikator keberhasilan yang diterapkan yaitu terjadi peningkatan sebesar 19\% dengan selisih kenaikan sebesar 16,17 pada lembar kegiatan observasi guru. Hal ini dapat dilihat pada siklus I nilai rata - rata observasi guru yaitu 66,92 menjadi 83,09. Pada lembar kegiatan observasi siswa terjadi peningkatan sebesar $37 \%$ dengan selisih kenaikan sebesar 17,71 dengan nilai rata - rata observasi siswa yaitu 61,98 menjadi 79,69 pada siklus II dari kriteria "Cukup" menjadi kriteria "Baik". Kemudian respons siswa terjadi peningkatan sebesar $14 \%$ dengan selisih kenaikan sebesar 11,2. Hal ini dapat dilihat pada siklus I skor rata yaitu 52,8 menjadi 64 dengan persentase $66 \%$ menjadi $80 \%$ pada siklus II. Pada ketuntasan hasil belajar terjadi peningkatan sebesar $44 \%$. Hal ini dapat dilihat pada persentase $28 \%$ menjadi $72 \%$. Dengan banyak siswa yang mencapai nilai KKM atau tuntas dalam pembelajaran 13 orang dari 18 orang yang mengikuti ujian.
\end{abstract}

This is an open access under the CC-BY-SA licence

All rights reserved.

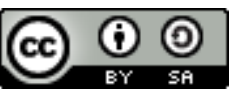

\section{Corresponding Author:}

Nenny Indrawati,

Pendidikan Matematika,

Universitas Sulawesi Barat

Email nennyindrawati@unsulbar.ac.id 
pengetahuannya maka pengetahuan siswa akan bertahan lama dan dapat digunakan dalam kehidupan sehari-hari siswa. Dengan demikian belajar akan menjadi bermakna bagi siswa. Terciptanya proses pembelajaran yang bermakna sangat tergantung pada kesiapan dan kemampuan serta kreativitas guru dalam menerapkan berbagai model pembelajaran.

Model pembelajaran yang memberikan kesempatan kepada siswa terlibat secara aktif dapat mengembangkan potensi siswa secara menyeluruh. Artinya tidak hanya pengetahuan saja yang bertambah, melainkan keterampilan dan sikap ilmiah siswa juga dapat berkembang secara optimal. Hal ini menyatakan bahwa hasil belajar yang dicapai sangat tergantung pada kegiatan pembelajaran yang diterapkan. Kegiatan pembelajaran merupakan kegiatan yang terdiri dari kegiatan belajar dan mengajar (Subekti, 2017). Kedua kegiatan tersebut saling berkaitan. Kegiatan belajar dan mengajar harus dilaksanakan dengan baik agar dapat membantu meningkatkan kualitas hasil belajar.

Hasil belajar dipengaruhi oleh stimulasi lingkungan yang ada. Stimulasi lingkungan tersebut dapat terjadi secara alamiah ataupun yang sengaja dibuat guru, misalnya melalui model pembelajaran yang diterapkan (Isa, 2017). Melalui penerapan model pembelajaran yang menarik akan dapat merangsang siswa untuk senang belajar.Praktik pembelajaran matematika di sekolah menurut kurikulum 2013 berdasarkan kemendikbud (Subekti, 2017: 136) seharusnya: (1) berpusat pada aktivitas siswa; (2) siswa diberi kebebasan berpikir memahami masalah, membangun strategi penyelesaian masalah, mengajukan ide-ide secara bebas dan terbuka; (3) guru melatih dan membimbing siswa berpikir kritis dan kreatif dalam menyelesaikan masalah; (4) upaya guru mengorganisasikan bekerjasama dalam kelompok belajar, melatih siswa berkomunikasi menggunakan grafik, diagram, skema, dan variabel; (5) seluruh hasil kerja siswa dipresentasikan untuk menemukan berbagai konsep, hasil penyelesaian masalah, aturan matematika yang ditemukan melalui proses pembelajaran.

Proses Pembelajaran di sekolah SMAN 1 Pamboang perlu dikembangkan untuk mengubah pola pembelajaran ke arah yang lebih baik melibatkan para siswa untuk aktif di dalam proses belajar sehingga dapat meningkatkan pencapaian hasil belajar para siswa. Berdasarkan hasil wawancara di sekolah SMAN 1 Pamboang, guru mengatakan bahwa sebagian besar siswa kelas XI MIPA 2 masih kurang dalam menyelesaikan masalah matematika disebabkan perhitungan dasar matematikanya masih kurang dan motivasinya juga masih perlu dikembangkan. Karna masih kebanyakan siswa menganggap bahwa pendidikan hanyalah sebagai kewajiban bukan sebagai kebutuhan. Berdasarkan pengamatan penulis selama melaksanakan PPL di SMAN 1 Pamboang ditemukan gejala yang berkenaan dengan rendahnya hasil belajar matematika siswa khususnya kelas XI MIPA 2. Di antara gejala tersebut adalah sebagai berikut: 1) sebagian siswa tidak menguasai materi pelajaran dengan baik, hal ini terlihat dari penilaian terhadap latihan dan ulangan, 2) Jika diberi soal yang menuntut pemahaman dan analisa, maka sebagian siswa tidak dapat menyelesaikannya dan nilai yang diperoleh siswa rendah, 3) Nilai ulangan harian siswa rendah, sekitar 50\% belum mencapai KKM yang telah ditetapkan yaitu 78,4 ) diberikan soal yang berbeda dari soal yang diberikan guru siswa tidak bisa menyelesaikannya.

Rendahnya hasil belajar siswa dapat dilihat pada nilai hasil ulangan harian siswa yang dilakukan pada pra tindakan. Dari hasil tes menunjukkan bahwa tingkat pemahaman dan kemampuan siswa dalam memecahkan masalah matematika masih rendah. Dari 25 siswa hanya 2 siswa yang mendapat nilai 78-100, sedangkan 18 siswa yang mendapat nilai 50-77 dan 5 siswa mendapat nilai di bawah 50. Dari nilai hasil belajar siswa tersebut, diketahui bahwa hasil belajar matematika siswa kelas XI MIPA 2 SMAN 1 Pamboang masih rendah atau di bawah KKM yang ditetapkan yaitu 78. Berdasarkan permasalahan yang dikemukakan di atas, maka penulis mengemukakan model Problem Based Learning (PBL) dalam pembelajaran matematika sehingga masalah di atas tentang pelaksanaan pembelajaran matematika dan hasil 
yang ingin dicapai sesuai dengan tujuan pembelajaran dapat diperoleh sebagaimana mestinya. Model pembelajaran yang dipilih untuk melaksanakan pembelajaran matematika adalah model problem based learning dengan pemberian tugas proyek, sebab model tersebut mampu mengembangkan kemampuan berpikir peserta didik untuk memecahkan masalah dan nantinya siswa tersebut akan diberikan tugas proyek secara berkelompok.

Model problem based learning merupakan salah satu model pembelajaran inovatif yang berangkat dari masalah dunia nyata peserta didik untuk belajar tentang cara berpikir kritis dalam memecahkan suatu permasalahan (Surya, 2017: 38-53). Menurut Ronis (Surya, 2017: 3853) "Problem based learning is based on the idea that individuals fashion their understanding largely throught what the experience". Pendapat Ronis tersebut jika diterjemahkan mengandung arti pembelajaran berbasis masalah didasarkan pada gagasan bahwa individu bisa paham terutama melalui pengalaman. Dengan demikian dapat disimpulkan bahwa dalam model problem based learning (PBL) peseta didik dihadapkan pada berbagai permasalahan untuk dicarikan solusinya oleh peserta didik. Permasalahan tersebut bersumber dari masalah nyata di lingkungan peserta didik yang bertujuan untuk mengembangkan kemampuan peserta didik berpikir secara kritis serta memiliki keterampilan untuk memecahkan suatu masalah.

Metode proyek merupakan metode instruksional yang melibatkan penggunaan alat dan bahan yang diusahakan oleh peserta didik secara perseorangan atau kelompok untuk mencari jawaban suatu masalah dengan perpanduan teori - teori dan dilaksanakan dalam jangka waktu tertentu, menghasilkan sebuah produk, yang hasilnya ditampilkan atau dipresentasikan.

Dengan penerapan model problem based learning dengan pemberian tugas proyek dapat menghubungkan pembelajaran dengan kehidupan dunia nyata karena masalah - masalah yang diangkat dalam pembelajaran biasa diambil dari kehidupan sehari-hari atau dari apa yang dialaminya. Tugas proyek mendidik siswa untuk berpikir secara sistematis, melatih siswa untuk mendesain suatu penemuan, merangsang perkembangan kemajuan berfikir siswa untuk menyelesaikan masalah yang dihadapi dengan tepat dan dapat mendidik siswa percaya diri sendiri. Selama pembelajaran matematika tersebut siswa akan dilatih memecahkan masalah melalui beberapa langkah model pembelajaran problem based learning dengan menghasilkan tugas proyek secara berkelompok berupa suatu makalah atau laporan berdasarkan materi matematika yang diajarkan. Dengan penerapan model problem based learning dengan pemberian tugas proyek, maka siswa akan lebih aktif dalam melakukan percobaan untuk memecahkan masalah matematika dan mengetahui peningkatan hasil belajar matematika siswa kelas XI MIPA 2 dengan model problem based learning dengan pemberian tugas proyek.

\section{Metode}

Penelitian ini menggunakan jenis Penelitian Tindakan Kelas (PTK) atau (classroom action researc). Menurut (Arikunto, 2015: 2) mengemukakan bahwa penelitian tindakan kelas atau yang dalam bahasa Inggrisnya disebut Classroom Action Research (CAR) yaitu sebuah kegiatan penelitian yang dilakukan di dalam kelas Penelitian ini dilaksanakan di SMAN 1 Pamboang, Kecamatan Pamboang, Kabupaten Majene Provinsi Sulawesi Barat. Penelitian ini dilaksanakan pada tanggal 28 juli sampai 27 agustus 2020 pada semester ganjil tahun ajaran 2020/2021. Adapun subjek penelitian ini yaitu siswa - siswi SMA Negeri 1 Pamboang kelas XI MIPA 2 dengan jumlah siswa sebanyak 25 siswa dari 8 laki - laki dan 17perempuan. Data yang digunakan dalam penelitian ini berupa data kualitatif (aktivitas guru dan aktivitas siswa) dan data kuantitatif (tes hasil belajar dan respons siswa). Penelitian yang akan dilaksanakan terdiri dari empat tahapan yakni perencanaan (planning), (2) pelaksanaan (action), (3) pengamatan (observation), (4) refleksi (reflektion). (Purnomo dan Mawarsari, 2014 : 24-31). 
Penelitian direncanakan selama 2 siklus dengan setiap siklus terdiri atas 5 kali pertemuan. Analisis data kualitatif dilakukan dengan tiga tahapan yaitu mereduksi data, penyajian data dan penarikan kesimpulan. Sebagai dasar untuk mengetahui keberhasilan tindakan serta pedoman analisis data maka diperlukan adanya indikator keberhasilan yaitu :(1) Ada peningkatan hasil belajar siswa sesuai dengan taraf minimal yang ditentukan, yaitu $71 \%$ dari jumlah siswa mengikuti proses pembelajaran telah mencapai nilai KKM sebesar 78. (2) Respon siswa terhadap pembelajaran berada pada kategori "Baik" dengan persentase $\geq 80 \%$.(3) Aktivitas siswa danguru sebagian besar terlaksana jika mencapai kriteria baik, yaitu berada pada kisaran persentase $70 \leq \mathrm{B} \leq 79$.

\section{Hasil Penelitian}

Pembelajaran problem based learning dilaksanakan dengan langkah - langkah : (1) Orientasi siswa pada masalah, (2) Mengorganisasi siswa untuk belajar, (3) Membimbing pengalaman individu/kelompok, (4) Mengembangkan dan menyajikan hasil karya, (5) Menganalisis dan mengevaluasi proses pemecahan masalah. Pendapat tersebut sesuai dengan (Nasution dan Surya, 2017:3).

Data hasil observasi yang diperoleh dari pengamatan terhadap guru menggunakan model problem based learning pada siklus I dan II, yaitu :

Tabel 1. Perbandingan Hasil Observasi Guru dan Observasi Siswa

\begin{tabular}{ccc}
\hline & Guru (\%) & Siswa (\%) \\
\hline Siklus 1 & 61,98 & 66,92 \\
\hline Siklus II & 83,09 & 79,69 \\
\hline
\end{tabular}

Dari tabel diatas dapat dijelaskan bahwa persentase langkah dalam penggunaan model problem based learning dengan pemberian tugas proyek terhadap guru pada siklus I mencapai $66,92 \%$ dan pada siklus II mencapai $83,09 \%$. Sedangkan persentase langkah penerapanmodel problem based learning dengan pemberian tugas proyek terhadap siswa pada siklus I mencapai $61,98 \%$ dan pada siklus II mencapai $79,69 \%$. Maka dapat disimpulkan bahwa langkah penggunaan model problem based learning dengan pemberian tugas proyek terhadap guru dan siswa telah mencapai indikator keberhasilan.

Tabel 2. Perbandingan Hasil Respons Siswa Pada Siklus I dan Siklus II

\begin{tabular}{ccc} 
& Skor Rata (\%) & Nilai (\%) \\
\hline Siklus 1 & 52,8 & 66 \\
\hline Siklus II & 64 & 80 \\
\hline
\end{tabular}

Dari tabel diatas menjelaskan bahwa pada siklus I skor rata sebesar 52,8 dengan persentase $66 \%$ dan pada siklus II skor rata sebesar 64 dengan persentase $80 \%$. Maka dapat dikatakan sudah mencapai indikator keberhasilan.

Tabel 3. Perbandingan Hasil Evaluasi Siswa Pada Siklus I dan Siklus II

\begin{tabular}{ll}
\hline Siklus I & Siklus II \\
\hline
\end{tabular}




\begin{tabular}{ccc}
\hline Jumlah Siswa ikut tes & 18 & 18 \\
\hline Jumlah Siswa tuntas & 5 & 13 \\
\hline $\begin{array}{c}\text { Presentase Hasil } \\
\text { Belajar Siswa }\end{array}$ & $28 \%$ & $72 \%$ \\
\hline
\end{tabular}

\section{Diskusi}

Permasalahan yang dihadapi dalam permasalahan ini adalah rendahnya hasil belajar siswa. Dari hasil tes menunjukkan bahwa tingkat pemahaman dan kemampuan siswa dalam memecahkan masalah matematika masih rendah. Kurangnya kerja kelompok dalam menyelesaikan suatu masalah. Adapun pembelajaran yang dapat membantu siswa dalam menyelesaikan suatu masalah matematika yaitu dengan menerapkan model problem based learning dengan pemberian tugas proyek. Dengan menerapkan model problem based learning dengan pemberian tugas proyek diharapkan dapat meningkatkan hasil belajar siswa.

Penelitian ini dilaksanakan dengan dua siklus selama 10 kali pertemuan yaitu 8 kali proses pembelajaran dan 2 kali tes akhir siklus dengan tahap - tahap penelitian yaitu orientasi siswa pada masalah, mengorganisasi siswa untuk belajar, membimbing pengalaman individu/kelompok, mengembangkan dan menyajikan hasil karya dan menganalisis dan mengevaluasi proses pemecahan masalah. Berikut adalah pembahasan dari hasil penelitian yang telah dilakukan.

Hasil belajar siswa diukur dengan menggunakan tes hasil belajar. Dalam penelitian menggunakan soal essay dimana pada siklus I soal tes hasil belajar sebanyak 5 nomor dan pada siklus II soal tes hasil belajar sebanyak 2 nomor sesuai dengan materi yang dipelajari pada setiap siklus. Dari hasil penelitian mengatakan bahwa dengan menerapkan model problem based learning dengan pemberian tugas proyek dapat meningkatkan hasil belajar siswa.

Dari hasil analisis data tes hasil belajar siswa bahwa nilai persentase hasil belajar yaitu 28\%. Hal ini mengatakan bahwa pada siklus I hasil belajar siswa belum mencapai indikator keberhasilan, sehingga dilanjutkan pada siklus berikutnya atau siklus II. Pada siklus II nilai persentase hasil belajar yaitu $72 \%$ sehingga hal ini menunjukkan bahwa pada siklus II hasil belajar siswa meningkat dan mencapai indikator keberhasilan. Hal ini dapat dikatakan bahwa siklus sudah dapat dihentikan.

Respon belajar siswa diukur dengan memberikan angket kepada siswa. Hasil penelitian menunjukkan bahwa setelah diterapkannya model problem based learning dengan pemberian tugas proyek dapat meningkatkan respon belajar siswa. Pada siklus I skor rata - rata pada siklus I sebesar 52,8 dengan nilai persentase 66 yang artinya respon belajar dapat dikatakan baik. Tetapi belum memenuhi indikator keberhasilan karna belum mencapai nilai persentase 80 . Sehingga untuk siklus berikutnya harus lebih baik lagi dalam proses pembelajaran. Hal ini dibuktikan pada siklus II bahwa perhitungan skor rata respon siswa terjadi peningkatan yaitu 64 dengan nilai persentase 80. Hal ini membuktikan bahwa sudah memenuhi indikator keberhasilan.

Aktivitas siswa diukur dengan lembar observasi yang dilakukan oleh observer. Pada siklus I untuk pertemuan pertama dengan nilai sebesar 66,67, untuk pertemuan kedua dengan nilai sebesar 62,5, untuk pertemuan ketiga dengan nilai sebesar 60,42 dan pertemuan keempat dengan nilai sebesar 58,33. Hal ini menunjukkan bahwa pada siklus I mengalami penurunan yang drastis. Disebabkan sejak pertemuan pertama sampai pertemuan keempat masih banyak siswa yang kurang memperhatikan materi yang dipelajari dengan baik sehingga menyebabkan siswa tidak terlalu paham dengan masalah yang diberikan, siswa masih kurang percaya diri 
dalam bertanya mengenai hal - hal yang belum dimengerti siswa, siswa masih kurang dalam belajar bersama atau dalam proses diskusi sehingga hanya beberapa siswa yangpaham dengan materi yang dipelajari, siswa juga kurang semangat dalam belajar karna prosespembelajaran sudah berbeda dari yang sebelumnya dan siswa juga kurang percaya diri untuk tampil di depan atau dalam mempresentasikan masalah yang telah dikerjakan. Pada siklus II untuk pertemuan pertama dengan nilai sebesar 70,83, untuk pertemuan kedua dengan nilai sebesar 77,08, untuk pertemuan ketiga dengan nilai sebesar 81,25 dan pertemuan terakhir dengan nilai sebesar 89,58. Hal ini menunjukkan bahwa aktivitas siswa pada siklus II terjadi peningkatan dan dapat dikatakan sudah memenuhi indikator keberhasilan.

Aktivitas guru diukur juga dengan lembar observasi yang dilakukan oleh observer. Pada siklus I untuk pertemuan pertama dengan nilai sebesar 69,12, untuk pertemuan kedua dengan nilai sebesar 67,65, untuk pertemuan ketiga dengan nilai sebesar 66,18 dan pertemuankeempat dengan nilai sebesar 64,71 . Hal ini menunjukkan bahwa pada siklus I mengalami penurunan yang drastis. Disebabkan sejak pertemuan pertama sampai pertemuan keempat guru masih kurang maksimal dalam mengarahkan siswa untuk proses pembelajaran yanglebih baik dengan menerapkan langkah - langkah model problem based learning, guru kurang memperhatikan tahap demi tahap dalam proses pembelajaran sehingga terkadang ada tahap yang terlupa pada saat pembelajaran berlangsung, dan guru kurang dalam memperhatikan siswa yang mengalami kesulitan dalam berlangsungnya pembelajaran. Pada siklus II untuk pertemuan pertama dengan nilai sebesar 73,53, untuk pertemuan kedua dengannilai sebesar 77,08, untuk pertemuan ketiga dengan nilai sebesar 83,82 dan pertemuan terakhir dengan nilai sebesar 95,59. Hal ini menunjukkan bahwa aktivitas guru pada siklus II terjadi peningkatan dan dapat dikatakan sudah memenuhi indikator keberhasilan.

Dari penelitian ini menghasilkan suatu tugas proyek yaitu berupa suatu laporan biasa. Pada siklus I menghasilkan tugas proyek mengenai soal - soal pertidaksaman linear dan menentukan model matematika dalam kehidupan sehari - hari yang dibuat oleh setiapkelompok dengan waktu selama sepekan yang nantinya akan dipresentasikan hasil tugas proyeknnya. Pada siklus II menghasilkan tugas proyeknya mengenai hasil wawancara dengan seorang pengusaha kemudian dari hasil wawancara dengan seorang pengusaha tersebut akan dibuatkan permasalahan yang nantinya akan diketahui berapa keuntungan yang diperoleh daripengusaha tersebut sehingga siswa dapat mengetahui manfaat materi program linear dalam kehidupan sehari - hari .

Hal ini sesuai dengan penelitian yang dilakukan oleh Situmorang \& Samosir (2018) dalam penelitiannya memberikan kesimpulan bahwa model pembelajaran Problem Based Learning (PBL) dapat meningkatkan hasil belajar siswa, dan penelitian yang juga dilakukan oleh Eko Andy Purnomo dan Venissa Dian Mawarsari (2014) menarik kesimpulan penelitian dengan memijak pada dua poin inti yaitu dihasilkan perangkatpembelajaran yaitu buku ajar materi persamaan kuadrat, peluang, trigonometri, turunan dan program linier yang baik dan implementasi model pembelajaran IDEAL problem solving berbasis PBL(Project Based Learning ) dapat meningkatkan kemampuan pemecahan masalah.

\section{Simpulan}

Berdasarkan hasil penelitian dan pembahasan maka dapat disimpulkan bahwa penerapan model problem based learning dengan pemberian tugas proyek dapat meningkatkan hasil belajar matematika pada siswa kelas XI MIPA 2 SMAN 1 PAMBOANG. Pertama, Adanya peningkatan pada rata - rata hasil belajar siswa dan persentase ketuntasan hasil belajar siswa. Persentase ketuntasan hasil belajar siswa pada siklus I sebesar $28 \%$, sedangkan pada siklus II sebesar 72\%. Dapat disimpulkan bahwa ketuntasan hasil belajar siswa mengalami 
peningkatan sebesar $44 \%$. Sehingga indikator keberhasilan pada poin pertama telah tercapai yaitu Ada peningkatan hasil belajar siswa sesuai dengan taraf minimal yang ditentukan, yaitu $71 \%$ dari jumlah siswa mengikuti proses pembelajaran telah mencapai nilai KKM sebesar 78 . Kedua, Data respon siswa pada siklus I skor rata sebesar 52,8 dengan persentase $66 \%$, sedangkanpada siklus II terjadi peningkatan dimana skor rata sebesar 64 dengan persentase 80\%. Sehingga indikator keberhasilan pada poin kedua telah tercapai yaitu Respon siswa terhadap pembelajaran berada pada kategori "Baik" dengan persentase $\geq 80 \%$. Ketiga, aktivitas guru dan aktivitas siswa, pada siklus I persentase aktivitas guru sebesar 66,92 dan persentase aktivitas siswa sebesar 61,98. Pada siklus II persentase aktivitas guru meningkat sebesar 83,09 dan persentase aktivitas siswa sebesar 79,69. Sehingga indikator keberhasilan yang ketiga telah tercapai yaitu Aktivitas siswa dan guru sebagian besar terlaksana jika mencapai kriteria baik, yaitu berada pada kisaran persentase $70 \leq \mathrm{B} \leq 79$.

\section{Konflik Kepentingan}

Penulis menyatakan tidak ada konflik kepentingan

\section{Referensi}

Arikunto, Suharsimi, dkk. 2015. Penelitian Tindakan Kelas.Suryani, editor. Jakarta : PT Bumi Aksara Bumi Aksara.

Isa, M. (2017). Pengaruh Model Problem Based Learning (Pbl) Terhadap Hasil Belajar Ekonomi Kelas X MAN 1 Kabupaten Tebo. Jurnal Penelitian Universitas Jambi Seri Sains.

Jauhar, S., \& Nurdin, M. (2017). Penerapan Model Pembelajaran Problem Solving Dalam Meningkatkan Hasil Belajar IPS Siswa SD. JIKAP PGSD: Jurnal Ilmiah Ilmu Kependidikan, 1(2), 141-149.

Lubis, M. A., \& Azizan, N. (2018). Penerapan model pembelajaran problem based learning untuk meningkatkan hasil belajar matematika di SMP Muhammadiyah 07 Medan Perjuangan Tahun Pelajaran 2018/2019. Logaritma: Jurnal Ilmu-ilmu Pendidikan dan Sains, 6(02), 150-163. Maryati, Iyam. 2018. Penerapan Model Pembelajaran Berbasis Masalah Pada Materi Pola Bilangan Di Kelas Vii Sekolah Menengah Pertama. Volume 7, Nomor 1, Januari 2018, (63-73).

Nasution, N. R., \& Surya, E. (2017). Penerapan Model Pembelajaran Berbasis Masalah (Problem Based Learning) Terhadap Kemampuan Berpikir Kreatif Matematika Siswa. Jurnal. Mahasiswa PPS Jurusan Pendidikan Matematika, Unimed.

Nasikun, A., Khair, A., \& Supriyadi, S. (2017). Penerapan Metode Problem Solving untuk Meningkatkan Aktivitas dan Hasil Belajar IPS. Pedagogi: Jurnal Pendidikan Dasar, 5(19).

Na'imah, N. J. (2015). Penerapan pembelajaran berbasis proyek berbantuan e-learning untuk meningkatkan hasil belajar siswa. Jurnal inovasi pendidikan kimia, 9(2), 1566-1574. 
Nurfitriyanti, M. (2016). Model Pembelajaran Project Based Learning Terhadap Kemampuan Pemecahan Masalah Matematika. Formatif: Jurnal Ilmiah Pendidikan MIPA, 6(2).

Santoso, B. (2016). Penerapan Model Problem Based Learning Dalam Peningkatan Pembelajaran Matematika Tentang Soal Cerita Pecahan Pada Siswa Kelas V Sd N 1 Kedungwinangun Tahun Ajaran 2015/2016.

Situmorang, M. S., \& Samosir, K. (2018). Penerapan Model Pembelajaran Problem Based Learning (Pbl) Untuk Meningkatkan Hasil Belajar Siswa Smp Negeri 1 Rantau Selatan. Inspiratif: Jurnal Pendidikan Matematika, 4(1).

Subekti, P. (2017). Penerapan model pembelajaran problem solving untuk meningkatkan hasil belajar IPA siswa kelas V. Briliant: Jurnal Riset dan Konseptual, 2(2), 130-139.

Surya, Y. F. (2017). Penerapan model pembelajaran problem based learning untuk meningkatkan hasil belajar matematika siswa kelas IV SDN 016 Langgini Kabupaten Kampar. Jurnal Cendekia: Jurnal Pendidikan Matematika, 1(1), 38-53. 